\title{
RESEARCH ON THE LIFETIME OF THE SWITCH AND ASSUMPTIONS OF INCREASING IT
}

\author{
Inesa Gailien $\dot{1}^{1}$, Igoris Podagèlis ${ }^{1}$, Olegas Slepakovas ${ }^{2}$ \\ ${ }^{1}$ Dept of Roads, Vilnius Gediminas Technical University, Sauletekio al. 11, LT-10223 Vilnius, Lithuania \\ E-mail: ingail@ap.vgtu.lt \\ ${ }^{2}$ SC Lithuanian Railways, M. K. Čiurlionio g. 16, LT-44360 Kaunas, Lithuania \\ E-mail: oslepakovas@railkaunas.lt
}

Received 15 May 2007; accepted 1 February 2008

\begin{abstract}
The switch is the most complicated and expensive component of a superstructure of the railway track. It requires particular attention and maintenance. The lifetime of the switch depends on its operating conditions and on a lifetime of its separate components, mostly the tongue and the frog. Defects of these two components emerge considerably earlier than that of the others. Reliable, uninterrupted and safe railway traffic depends on condition of the switch components. Condition of the switch components depends on their maintenance and determination and elimination of the defects in time. A very important task is to assure qualitative, long-lasting and cost-efficient switch appliance. In order to realize these objectives it is necessary: to improve the switch construction; to use materials that should have improved physical and mechanical characteristics for the manufacture of the switch; to improve organization and performance of the switch maintenance and repair applying modern techniques and methods. In order to determine dependence of load amount on tongue, frog and stock rail wear, analysis of technical and running conditions of replaced switches in the stations of Lithuanian railway lines in 2002, 2003 and 2005, is presented in the article. Authors' purpose is: to determine wear reasons of switch components; to examine load amount dependence on tongue, frog and stock rail wear and to submit the suggestions on improving the switch construction, installation and maintenance in order to increase the lifetime of the switch.
\end{abstract}

Keywords: switch, tongue, frog, stock rail, lifetime, load amount, wear (wearing).

\section{Introduction}

The main task of the railway transport is safe and convenient passenger and freight delivery to the indicated place. Train speeds in Lithuanian railway lines are noticeably lower than those in West Europe. In order to increase train speeds it is necessary to improve condition of the maintained railroads, that is to improve geometrical and technical characteristics of the track plane and strengthen substructure and superstructure of the railway track (Sakalauskas 1998).

The largest stream of trains through Lithuania is by transit. It means that the transit trains pass railway stations nonstop and their speed decreases while passing through the switches. Such situation results in decreased total average speed. Consequently, having a purpose to increase the train speed it is necessary to improve the switch construction, technical conditions and maintenance. Not qualitative and worn switch components markedly reduce train speed, cause discomfort for the passengers because of impermissible wagon side swing and put in danger safety of train traffic.
Railway switches and crossings are representing an important asset of railway networks. Approximately 4000 of these devices allow the trains on the Lithuanian railway network to run as they do today. In case of disruptions they form an even more important asset, allowing for trains to use other routes than usual, or to use a track in the opposite direction, to assure a reliable train service for the passengers. By Zwanenburg (2006) this however comes with a cost: 20 to $40 \%$ of the track maintenance budget is spent on the inspection, maintenance and renewal of switches and crossings. This relatively high expenditure (the maintenance costs of one switch or crossing equals the maintenance costs of 300 to $500 \mathrm{~m}$ of plain track) is mainly due to the nature of switches and crossings that makes them absolutely and relatively more expensive to maintain than plain track (straights and curves):

- Switches and crossings have special components e.g. switch tongues, frogs, slide plates, exposed to high static and dynamic forces, thus showing high wear rates and specific deterioration; 
- Switches and crossings have moving parts, which require extra regular inspections and maintenance actions e.g. greasing, to avoid poor reliability;

- Switches and crossings form a potential safety hazard, due to moving parts, which in case of malfunctioning (or worse: breaking) can immediately cause serious accidents, thus requiring immediate action in case problems are detected - where simple track sometimes can sustain its function due to built-in redundancy.

Switch is one of the most complicated components of the superstructure of a railway track. It needs particular service during exploitation. The lifetime of the switch depends on maintenance conditions and durability of separate components, such as the frog, the tongue and the stock rail. Defects of these components emerge considerably earlier than that of the others. The main reasons for the switch replacement are metal crumbling and wear of the switch rolling surface and working edge. As train speeds, load intensity and rolling stock axial load rapidly increases, switch loads increase as well. Therefore a very important task is to assure qualitative, long-lasting and cost-efficient switch maintenance. Replacement, repair and service of the switch components are very expensive (for example, by Judge (2002), USA spends 300 million dollars for replacement of the switch components and 500 million dollars for their service and repair annually). Therefore, it stands no reason that the research is performed in order to increase the lifetime of the switch and other components of the superstructure (for example, the lifetime of the rails on curves by Povilaitiene and Podagèlis (2003), Povilaitienè and Laurinavičius (2004), Povilaitiené, Podagèlis and Kamaitis (2004)).

Often the object of the scientific research by PITA (2005), Markov (Марков, 2004), Tuzik (2000), Bureika and Subačius (2002), Ewans and Iwnicki (2002) is wheelrail interaction and increment of the lifetime of the rail. However, researches, analyzing the switch as a component of the rail track superstructure and the switch components, are missing. Though, recently, by Gliuzberg et al. (Глюзберг и др. 2002) discussions about importance of forecasting the lifetime of the switch and its components, in order to plan expenses concerning replacement of the switch components, have become more important. Generally, the switch research by Kageyama and Hori (2001), Davis (2002) involves analysis of improvement possibilities of the switch construction.

The following is analyzed in the article: peculiarity of the switch construction, wear dynamics of the separate components, factors influencing wear of the switch components and possibilities of increasing the lifetime of the switch. Research on the dependence of the switch tongue, frog and stock rail wear on load amount is presented as well. The research has been performed on the switches in the stations of Lithuanian railway lines.

\section{Switches, their components and factors influencing their wear}

The switch is a complicated and important component of a superstructure of the railway track. It has over 2000 various details weighing more than 30 tons. The main components are: the stock rail, tongue, frog, guardrail, checkrails, switch sleepers and switch motor. The main components of a normal switch are presented in Fig. 1.

The object of the research in this article is tongue, frog and stock rail wear. The tongue is a pointed switch part which is attracted or retracted from the stock rail, guiding the rolling-stock towards one or another track. One switch edge is cut (whittled away) cornerwise, so that it is closely flattened against the stock rail. The tongues can be cut both cornerwise and vertical. The rails used for the tongue manufacture can have standard or special cross-section. The rails with a special crosssection used for the tongue manufacture increase tongue toughness and strength. When the rails with standard profile are used, the tongue flange has to be cut in order that the tongue could closely flatten against the stock rail. However this decreases tongue strength and resistance. Nowadays the tongues with standard profiles are not manufactured anymore. The stock rail is a part of the lateral track rail where the switch is connected. The tongue is flattened against it. The frog is a part of the switch in-

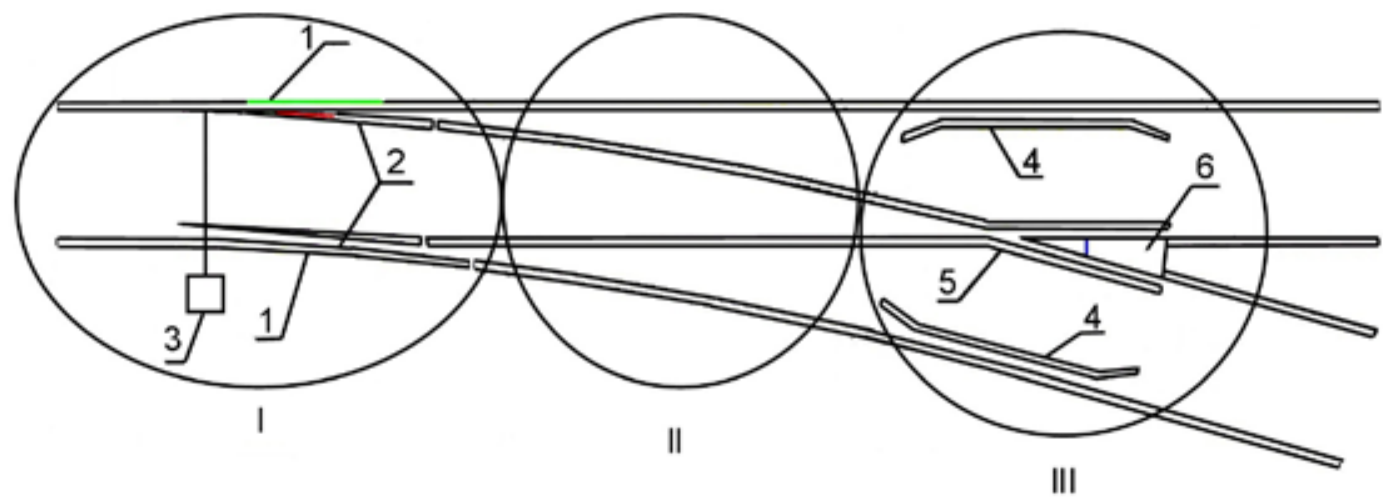

Fig. 1. Scheme of single normal switch: I - tongue segment; II - connecting segment; III - frog and guardrail segment; 1 - stock rail; 2 - tongues; 3 - switch motor; 4 - guardrails; 5 - frog checkrails; 6 - frog core; measurement place of the tongue lateral wear is marked in red, measurement place of the frog core vertical wear is marked in blue and measurement place of the stock rail vertical wear is marked in green 


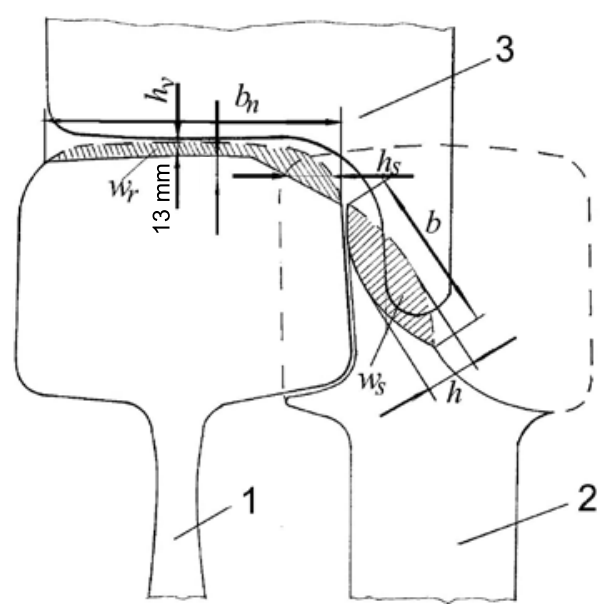

Fig. 2. Wear scheme of the stock rail and tongue: 1 - tongue; 2 - stock rail; 3 - wheel; $w_{r}$ - cross-sectional area of stock rail wear, $\mathrm{mm}^{2} ; w_{s}$ - cross-sectional area of tongue wear, $\mathrm{mm}^{2}$; $b$ - width of tongue wear, $\mathrm{mm} ; h$ - height of tongue wear, $\mathrm{mm} ; b_{n}-$ width of stock rail wear, $\mathrm{mm} ; h_{\check{s}}$-stock rail lateral wear, $\mathrm{mm} ; h_{v}-$ stock rail vertical wear, $\mathrm{mm}$

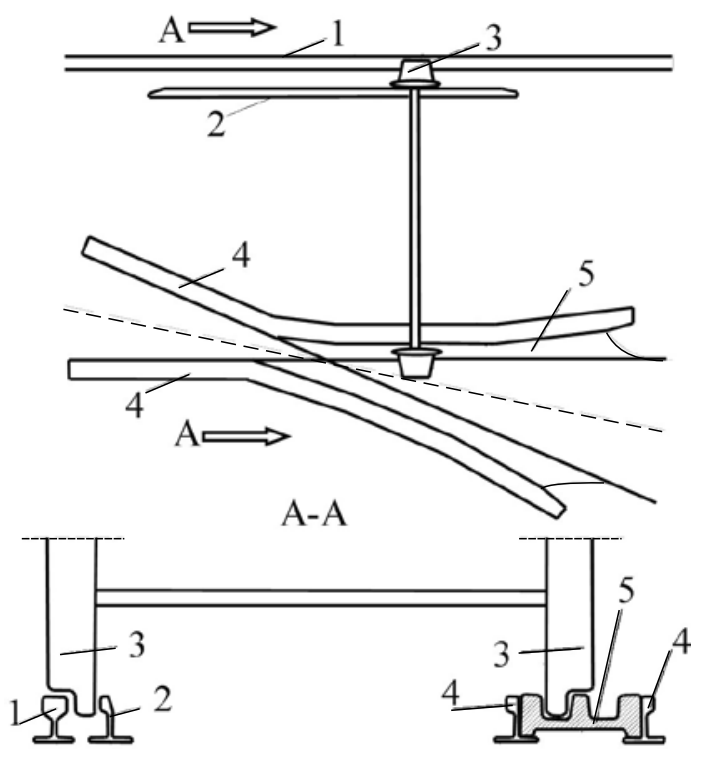

Fig. 3. Wear scheme of frog core and checkrails: 1 - stock rail; 2 - guardrail; 3 - wheel; 4 - checkrail; 5 - frog core

tended for safe rolling-stock passing through the crossing rails. The main components of the frog are: the core (It is the main component of the frog. The wheel fillet of a running rolling-stock rests against one of the running edges of the core) and the checkrails (bended rails of a crossover (straight and deviated tracks) placed in both sides of the frog core).

The railway track is uneven in both horizontal and vertical directions. Existing roughness causes additional tension. Thus the rail and rolling stock wear is accelerated. The switch constructional features cause additional roughness, when the rolling-stock passes through the switch. Roughness in vertical direction originates when the wheel passes through the tongue and frog. Roughness in horizontal direction originates when the track width changes. It causes wheel fillet hitting the checkrails. Additional tension also exists in the track formation, because the switch sleepers have different length and their epure changes within width of the switch.

Wear of the following switch components is the most often and intensive: the stock rail in outer part of the side track curve, the tongue and the frog (vertical wear). One of the mostly worn components is tongue. Its replacement is technically complicated and expensive. The stock rails can be simply replaced or polished and maintained for several more years. The frogs and the checkrails are restored by welding a new upper metal layer. The stock rail and tongue wear scheme is presented in Fig. 2. Tongue and stock rail wear is measured $13 \mathrm{~mm}$ below the rail surface, where the rails touch the wheel. The frog core and checkrail wear scheme is presented in Fig. 3.

In the switches, amount of wear differs from point to point. The end of the frog is the most resistant point to wear. However, the beginning of the frog and the beginning of the switch blade are most prone to vertical wear while the middle of the switch blade is more prone to lateral wear. The most influential geometric parameter in the switch wear is gauge deficiency (particularly for the case of lateral wear), presented by Sadeghi and Akbari (2006).

Switch service includes visual inspection and inspection using technical means. The purpose of control is to estimate partial or critical switch component breaking in time, as they can cause danger for safe railway traffic or can restrict railway maintenance. According to the inspection results it has to be decided what means should be applied: continue exploitation of the existing switch, replace the switch or its components, restrict speed of the train or perform some repairs.

The lifetime of the switch main components is directly dependent on maintenance conditions, i.e. train speed, load intensity and axial load normative tonnage. The latter factor has to be evaluated by applying the defining method and periodicity of inspection. Numerical indicators characterizing reliable operation of the switch components are: trouble-free operation probability and breakdown intensity depending on the passed tonnage. Breakdown intensity increases with growing load amount. This factor has to be evaluated by applying the defining method and periodicity of inspection, presented by Povilaitiene et al. (Повилайтене et al. 2006) research.

\section{Field investigation on tongue, stock rail and frog wear and switch lifetime}

The switches replaced in 2002, 2003 and 2005 in Vilnius, Lentvaris, Kyviškis, Paneriai and Vaidotai stations have been chosen for the investigation. Load amount passing through the switches during the replacement has been estimated. According to the directions the following has been measured (see Geležinkelio kelio priežiūros taisyklès 2000): tongue lateral wear $13 \mathrm{~mm}$ below the upper rail edge, where tongue cross-section is $20 \mathrm{~mm}$; stock rail vertical wear of an outer rail in the middle of a switch curve; frog core verti- 


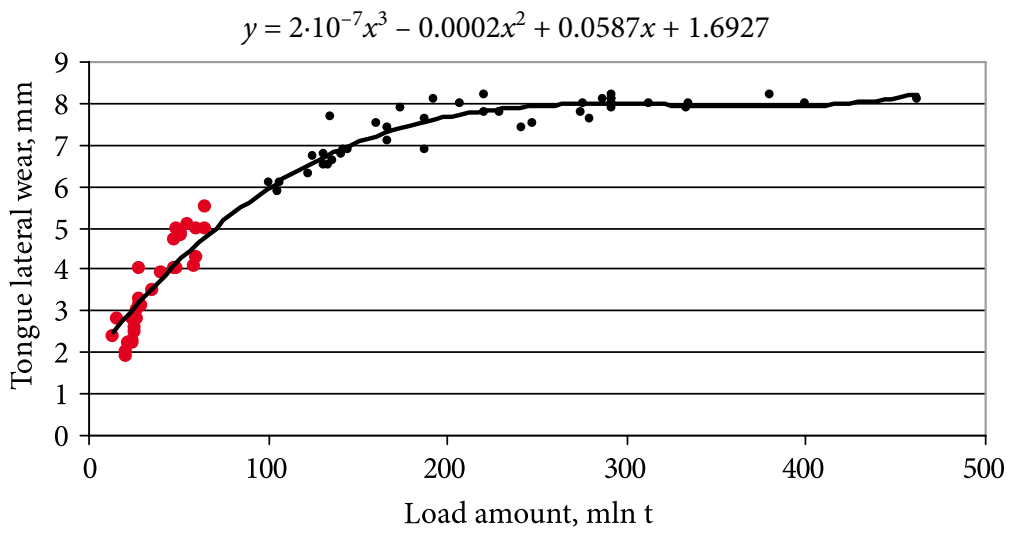

Fig. 4. Tongue lateral wear dependence on load amount (correlation coefficient - 0.894). Data received during our research is marked in black and data (Davis 2002) is marked in red

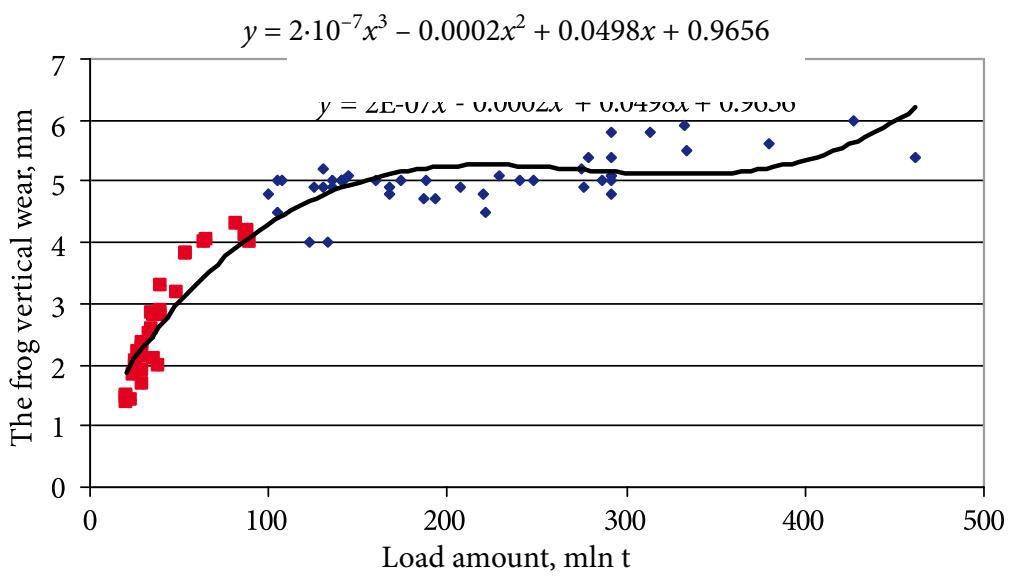

Fig. 5. Dependence of the frog core vertical wear on load amount (correlation coefficient - 0.81). Data received during our research is marked in blue and data (Davis 2002) is marked in red

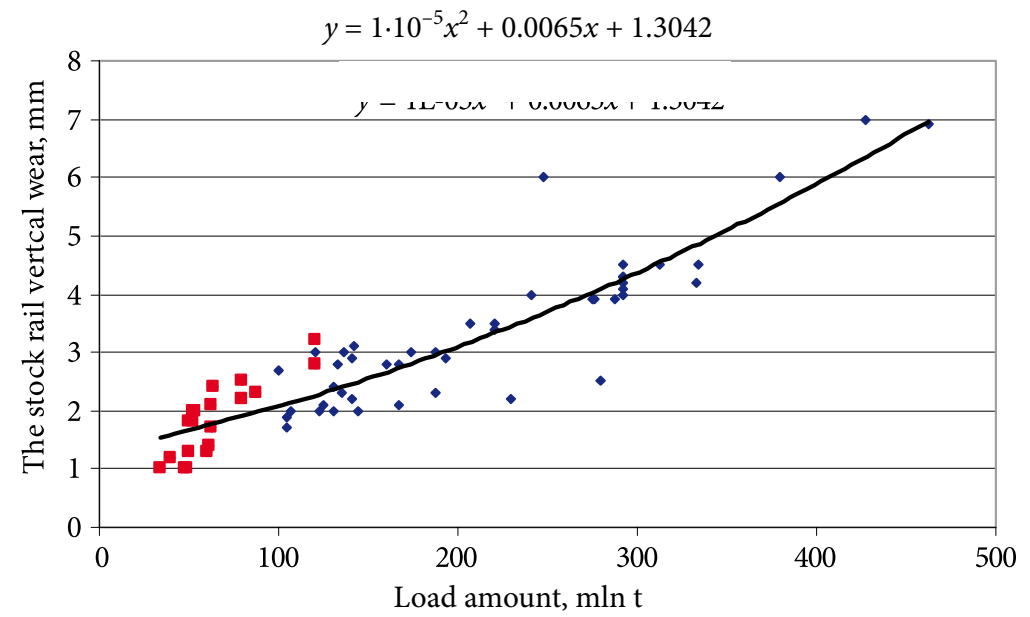

Fig. 6. Dependence of the stock rail vertical wear on load amount (correlation coefficient - 0.9). Data received during our research is marked in blue and data (Davis 2002) is marked in red

cal wear in the middle of a roll surface, in the cross-section, which is $13 \mathrm{~mm}$ bellow the roll surface and is equal to 40 $\mathrm{mm}$. Vertical wear of the frog core and stock rail has been measured using track vernier clippers. Tongue lateral wear has been measured using a special template. Measurement places are seen in Fig. 1. The investigative switches are R65 and UIC60 rail type and switch frog mark is 1/11.
It should be noted that, general condition of all replaceable switches was unsatisfactory or very poor: high level of breakstone impurity (up to $80 \%$ ), rotten switch beams and noticed deviations comparing with the designed values in plane and profile views. The lifetime of the different rails (i.e. amount of loads passed before the switch replacement) is very uneven, although technical 
conditions are rather the same. Therefore it can be concluded that service of high quality switches is poor. According to the performed investigations and after analysis of received data, dependence of tongue lateral wear, stock rail and frog core vertical wear on load intensity has been estimated (Figs. 4, 5 and 6). Our investigations have been linked up with the investigations of Braželis (2003). The results, i.e. dependence of tongue lateral wear on load amount are presented in Fig. 3. Therefore tongue lateral wear dependence on load intensity is presented starting from the very beginning of the switch replacement, i.e. when load amount is very small, until the moment the permissible tongue lateral wear approaches or is near the permissible value. Data analysis with confidence level of $95 \%$ has been performed.

As the investigation results show, the switch components wear intensity is very high. Therefore, it is necessary to find the methods how to increase the lifetime of the switch components and at the same time reduce expenses for replacement of the switch components. Therefore, direction of further investigations is to improve the switch construction, i.e. one of the possibilities is being analyzed - enlarge the cross-section of the pointed tongue, presuming that it would increase the lifetime of the tongue. Another researchable possibility to increase the switch components lifetime is to tighten deviation tolerance of width of the gauge, when driving into the switch (at the joint of the stock rail, see Fig. 1): from $+4 \mathrm{~mm}$ to $+2 \mathrm{~mm}$ to the wider side and from -2 $\mathrm{mm}$ to $0 \mathrm{~mm}$ to the narrower side, in order that the rolling stock wheels drive into the switch with the lowest dynamic force. Also tighten the gauge geometrical parameters from $\pm 2 \mathrm{~mm}$ to $\pm 0 \mathrm{~mm}$ before the pointed tongue. Also the assumption, that the dynamic force, caused by the rolling-stock wheels driving into the switch, could be decreased by mounting the guardrails before the pointed tongue, is made. All of the mentioned possibilities how to increase the lifetime of the switch are being analyzed and theoretical as well as experimental investigations are being performed at the moment.

\section{Conclusions}

1. The switch is one of the most complicated components of a superstructure of the railway track. It needs particular service during exploitation. The lifetime of the switch depends on maintenance conditions and toughness of its separate components, such as the frog, tongue and stock rail. Defects of these elements emerge much earlier than that of the others. Therefore the object of this research is analysis of reasons causing switch tongue, frog and stock rail wear and dependence of wear on load amount. The investigations on dependence of wear on load amount have been performed in the switches of Lithuanian railway stations.

2. The research has been performed on the switches replaced in 2002, 2003 and 2005 in Vilnius, Lentvaris, Paneriai, Kyviškis and Vaidotai stations. Tongue lateral wear as well as frog and stock rail vertical wear were measured at the moment of switch replacement. Dependence of the mentioned wear on load amount has been estimated.

3. It has been estimated that intensity of tongue lateral wear is high at the beginning of maintenance (up to 100 million tons it reaches $6 \mathrm{~mm}$ and later wear intensity decreases). Rail type does not influence formation of tongue lateral wear. Frog core vertical wear is intensive at the beginning of maintenance (up to 120 million tons). Later the intensity decreases and starts increasing again when load amount approaches 400 million tons.

4. After the research it was noticed that before the replacement of the switches load amount was uneven and markedly differed, although technical characteristics (ballast impurity, amount of rotten sleepers, rail wear and track roughness in plane and longitudinal profile) were very similar. Therefore it can be concluded that switch service markedly influences their lifetime. Thus it is stated that the regular service of the switches, eliminating observed defects in time, has to be performed.

5. Direction of further investigations is to improve the switch construction, i.e. one of the possibilities is being analyzed - enlarge the cross-section of the pointed tongue, presuming that it would increase the lifetime of the tongue. Another researchable possibility to increase the switch components lifetime is to tighten the gauge width deviation tolerance driving into the switch (in the joint of a stock rail, see Fig. 1): from $+4 \mathrm{~mm}$ to $+2 \mathrm{~mm}$ to the wider side and from $-2 \mathrm{~mm}$ to $0 \mathrm{~mm}$ to the narrower side, in order that the rolling stock wheels drive into the switch with the lowest dynamic force. Also tighten the gauge geometrical parameters from $\pm 2 \mathrm{~mm}$ to $\pm 0 \mathrm{~mm}$ before the pointed tongue. Also the assumption, that the dynamic force, caused by the rolling-stock wheels driving into the switch, could be decreased by mounting the guardrails before the pointed tongue, is made.

\section{References}

Bureika, G.; Subačius, R. 2002. Mathematical model of dynamic interaction between wheel-set and rail track, Transport 17(2): 46-51.

Braželis, A. 2003. Iešmų elementų dilimo analizè. Baigiamasis magistro darbas [The analysis of elements of switch wear. Master's final project]. Vilnius. 74 p. (in Lithuanian).

Davis, D. 2002. Improvement of construction of the switch components, International Railway Journal 3: 24-25.

Ewans, J.; Iwnicki, S. D. 2002. Vehicle dynamics and the wheel/ rail interface, The Rail Technology Unit, 19.

Judge, T. 2002. New construction of the switch and lead cross components, Railway Age 9: 87-91.

Kageyama, T.; Hori, Y. 2001. The switches of new generation, International Railway Journal 9: 25-26.

K/111 Geležinkelio kelio priežiūros taisyklès 2000 [The rules of railway service]. 213 p. (in Lithuanian).

Pita, A. L. 2005. Optimizing the quality of the system, cost-efficiency, financing, Railway Technical Review 3: 8-12.

Povilaitiene, I.; Podagelis, I. 2003. Research into rail side wearing on curves, Transport 18(3): 124-129. 
Povilaitienè, I.; Laurinavičius, A. 2004. Reduction of external rail wearing on road curves, Journal of Civil Engineering and Management 10(2): 123-130.

Povilaitiene, I.; Podagelis, I.; Kamaitis, I. Z. 2004. Influence of gauge width on rail side wear on track curves, Journal of Civil Engineering and Management 12(3): 255-260.

Sadeghi, J.; Akbari, B. 2006. Field investigation on effects of railway track geometric parameters on rail wear, Journal of Zhejiang University 7(11): 1846-1855.

Sakalauskas, K. 1998. Geležinkelio plano kreivių rekonstrukcijos tikslingumo nustatymas [Estimation of purposefulness of reconstruction, performed on curves in railway plan], Transport 13(1): 40-42 (in Lithuanian).

Tuzik, R. E. 2000. Optimization of rail and wheel interaction, Railway Age 7: 42-43.

Zwanenburg, W.-J. 2006. Modelling degradation processes of switches and crossings for maintenance and renewal planning on the Swiss railway network (First results from the literature study), in $6^{\text {th }}$ Swiss Transport Research Conference. $11 \mathrm{p}$.

Глюзберг, Б. Э.; Титаренко, М. И.; Калачев, А. М.; Саватеева, Е. В.; Корнева, С. М. 2002. Анализ отказов основных элементов стрелочных переводов с определением показателей надежности [Analysis of the defects of the main switch components, estimating reliability indices], Вестник ВНИИЖТ 1. 18 p. (in Russian).

Марков, Д. П. 2004. Оптимизация колесно-рельсовой трибосистемы [Optimization of wheel/rail system], Вестник ВНИИЖТ 6. 12 p. (in Russian).

Повилайтене, И.; Слепаковас, О.; Подагелис, И. 2006. Особенности содержания стрелочных переводов на железнодорожных линиях Литвы [Peculiarities of switch maintenance in Lithuanian railways], in Scientific works of the third science-technology conference "Existing problems of designing, building and maintaining railways", Москва: МИИТ, 193-196 (in Russian). 